\title{
A investigação criminal direta pela defesa - instrumento de qualificação do debate probatório na relação processual penal
}

\author{
Criminal Defense Investigation - instrument to improve \\ the evidence debate in the criminal procedure \\ L'indagine difensiva - strumento di qualificazione \\ del dibattito probatorio nella procedura penale
}

\section{Franklyn Roger Alves Silva ${ }^{1}$}

\author{
Universidade Cândido Mendes - Rio de Janeiro, RJ, Brasil \\ franklyn.roger@gmail.com \\ http://lattes.cnpq.br/7268807770125558 \\ http://orcid.org/0000-0002-4863-3507
}

\begin{abstract}
Resumo: O presente artigo examina a investigação criminal defensiva no sistema jurídico brasileiro como um instrumento necessário à qualificação da atividade probatória defensiva no processo penal. Apesar da falta de regulamentação normativa da possibilidade de busca de elementos de formação do convencimento pela defesa, o presente estudo demonstra o potencial do processo penal brasileiro a partir da experiência italiana e norte-americana e a recente regulamentação através de normativa OAB.
\end{abstract}

Palavras-chave: Processo Penal; Investigação criminal defensiva; Atividade probatória; Defensoria Pública; Advocacia.

ABSTRACT: The present article examines criminal defense investigation in Brazilian legal system as an instrument necessary to improve the production of evidence

1 Doutor e Mestre em Direito Processual pela Universidade do Estado do Rio de Janeiro (UERJ) com período sanduíche na Università degli studi di Pavia. Professor de Processo Penal na Universidade Cândido Mendes. Defensor Publico do Estado do Rio de Janeiro. 
in the criminal procedure. Although there are not rules about defense search for evidence, the study demonstrates the potential for Brazilian criminal procedure law based on Italian and North American experience, as well as the recent standard edited by the Brazilian Bar Association.

KeYwords: Criminal procedure; Criminal defense investigation; Evidence; Public Defender's Office; Legal representation.

RIASsUNTO: Questo articolo esamina l'indagine difensiva nel sistema legale brasiliano come strumento necessario per la qualificazione dell'attività probatoria difensiva nei procedimenti penali. Nonostante la mancanza di regolamentazione normativa della possibilità di cercare elementi di formazione delle condanne da parte della difesa, il presente studio dimostra il potenziale del processo criminale brasiliano davanti l'esperienza italiana, nordamericana e la recente regola dell'Ordine degli Avvocati Brasiliani.

Parole chiave: Procedura Penale; Indagine Difensiva; Attività probatoria; Difesa d'ufficio; Avvocatura.

SUMÁRIo: Introdução; I - A investigação defensiva no direito comparado; I.1 - A Investigação criminal defensiva na Itália; I.2 - A Investigação criminal defensiva nos Estados Unidos da América; II - O potencial do sistema jurídico brasileiro no campo da investigação criminal defensiva; II.1 - Suporte normativo para a investigação defensiva; II.2 - A ampla defesa e contraditório como princípios norteadores; II.3 - A definição da investigação defensiva no Brasil; III - A teoria da investigação criminal defensiva e a carência normativa a ser suprida; Conclusão; Referências.

\section{INTRODUÇÃO}

Em nosso sistema processual penal a atividade defensiva foi construída a partir de uma premissa de resistência à pretensão. O desenho do Código de Processo Penal atribui o encargo probatório ao Ministério Público, ainda que de forma dúbia e incompleta e prevê o papel da defesa técnica no processo penal, sem, contudo, trazer um regramento eficaz da atuação defensiva na fase pré-processual. 
A investigação criminal direta pela defesa ou investigação defensiva corresponde a uma atividade de coleta de elementos desempenhada pelo advogado ou Defensoria Pública, com propósitos e metodologia específicos, a partir de regras deontológicas e transparência no atuar defensivo, sempre em vistas a proporcionar a imediação da defesa com o conteúdo probatório e permitir a elucidação do fato criminoso dentro de uma perspectiva de boa-fé, paridade de armas e lealdade na relação processual.

A proposta deste estudo é a de analisar brevemente o tema, como uma alternativa à ausência de um sistema normativo capaz de balancear a produção adequada das provas no processo e a colheita de informações na fase de investigação, assegurando o verdadeiro e tão propalado equilíbrio de armas entre acusação e defesa.

A doutrina processual penal não evoluiu no tempo quando o assunto diz respeito à disciplina probatória. Predomina uma concepção legislativa de que o nosso sistema processual continua moderno e que o regramento probatório não necessita de reformulação.

A pouca perspectiva do Poder Legislativo também é um balde de água fria quando falamos em compartilhamento prévio de informações entre as partes no processo penal e investigação direta pela defesa. Apesar de tramitar há quase 10 anos o projeto de novo Código de Processo Penal, não se percebe um debate sobre a participação ativa e autônoma da defesa na coleta de fontes de prova. O projeto de novo CPP, ao menos por ora, restringe-se a um único dispositivo.

A Ordem dos Advogados do Brasil, em resposta ao fenômeno de intensa persecução à corrupção, desenhou uma proposta normativa de regramento da investigação defensiva, resumida em poucos dispositivos que não contribuem para a incorporação eficaz do tema.

Partimos, desde já, da premissa de que se à defesa for facultada a possibilidade de colher elementos capazes de consubstanciar as teses em favor do investigado, melhor será o exercício da resistência à pretensão acusatória.

A fisiologia da função acusatória e da função defensiva precisa de um novo referencial, pois de nada adianta falar em aptidão probatória se não reconhecida a paridade e equilíbrio de armas entre os sujeitos da relação processual. 
Essa remodelação certamente conduzirá também o pensamento em torno de uma defesa pública capaz de fornecer suporte à defesa de iniciativa privada, sempre com foco na tutela de interesses do imputado, fortalecendo o palco processual, especialmente se levarmos em conta que esse pensamento já foi veiculado desde o século XIX, conforme lições de Bentham:

"Então, é essencial estabelecer ostensivamente, ao lado do magistrado que apura a conduta criminal aquele que zela pela inocência, de não conceder a acusação nenhuma vantagem não compartilhada igualmente pelo defensor e de separar essas duas funções daquela julgadora, para permitir ao magistrado a imparcialidade por completo. Esses dois profissionais legais não devem prestar suas atividades aos clientes que lhes paguem. Eles se referem ao público e não é adequado expor a justiça a retardamentos derivados de interesses particulares. As causas dos pobres seriam frequentemente adiadas, pois o advogado não estaria disponível, já que o tempo que ele deve dedicar aos clientes insolvíveis seria utilizado em prol daqueles que possam remunerá-lo". ${ }^{2}$

Assim, então, parece-nos pertinente debutarmos neste estudo com um breve panorama da investigação defensiva no direito comparado, de modo a entendermos o seu embasamento e funcionamento para, em seguida, adentramos em solo brasileiro e verificarmos a sua aplicabilidade e limites normativos.

\section{I - A Investigação Defensiva no Direito Comparado}

Com o propósito de estudo comparado, iniciaremos a abordagem deste tópico com a estrutura investigativa do sistema processual italiano e, na sequência, o sistema norte-americano.

Opta-se pela seleção destes dois países por serem os principais berços da investigação criminal defensiva. Ao mesmo tempo, são países estruturados sob sistemas diversos, a Itália sob a matriz da civil law,

2 BENTHAM, Jérémie. De l'organisation judiciare, et de la codification. Paris: Librairie de Hector Bossange, 1828. p. 113 (tradução livre). 
escorada em um ordenamento jurídico codificado, enquanto que os Estados Unidos da América, um modelo de common law, onde a normativa advém de precedentes.

A análise comparada permite o aprimoramento e delineamento das principais características da investigação defensiva, contribuindo para a fixação do tema no sistema brasileiro.

\section{I.1 - A InVESTIGAÇ̃̃o CRIMINAL deFENSIVA NA ITÁLIA}

Diferentemente do processo penal brasileiro, a disciplina processual penal italiana é mais contemporânea, especialmente o seu texto constitucional e o Código de Processo Penal, superando o modelo anteriormente editado no período fascista.

Donatella Curtotti explica que a sede normativa da investigação criminal defensiva na Itália decorre da inviolabilidade do direito à defesa técnica previsto na Constituição e do direito de se defender provando como um desdobramento da paridade de armas:

"O fundamento da investigação defensiva, há muito, é identificado
no direito de defesa, reconhecido pela Carta Constitucional como
inviolável em todos os estados e graus do processo (artigo 24 ,
parágrafo $2^{\circ}$ ). Após a lei constitucional n. $2 / 1999$, não há dúvida
de que o direito de se defender no âmbito de investigações preli-
minares é também expresso pelo princípio da igualdade das partes
(artigo 111 , parágrafo $2^{\circ}$ ) e o direito de "dispor do tempo e das
condições necessárias para preparar a [...] defesa". (tradução livre) ${ }^{3}$

3 "Il fondamento dell'investigazione difensiva penale è stato individuato da tempo nel diritto di difesa, riconosciuto dalla Carta costituzionale come inviolabile in ogni stato e grado del procedimento (art. 24 comma 2). Dopo la legge costituzionale n. $2 / 1999$, non c'è dubbio che il diritto di difendersi sin dalle indagini preliminari sia espressa attuazione anche del principio di parità delle parti (art. 111 comma 2) e del diritto di "disporre del tempo e delle condizioni necessarie per preparare la [...] difesa' (art. 111 comma 3).” (CURTOTTI, Donatella. L'esercizio del diritto di difesa nelle indagini preliminari. In: NEGRI, Daniele. Le indagini preliminari e l'udienza preliminare. Torino: G. Giappichelli Editore, 2017. p. 329 (Trattato teorico pratico di diritto processuale penale, v. 5). 
Seria irresponsável afirmar que a origem da investigação criminal defensiva decorre da Lei 397, de 7 de dezembro de 2000, sem que fosse contextualizado todo o processo evolutivo em torno do citado diploma e o clima de resistência à referida atividade. Por isso, faremos um breve retrospecto do panorama normativo da indagine defensiva na Itália.

Durante décadas, a iniciativa da defesa na atividade investigatória foi censurada pelo ordenamento jurídico, como ocorria à época do revogado Código Rocco, em virtude de uma jurisprudência disciplinar muito rigorosa ${ }^{4}$.

A própria estrutura procedimental não contribuía para o exercício da atividade probatória da defesa, considerando a divisão bifásica do procedimento em momentos distintos; o da instrução, de caráter secreto e destinado à coleta de elementos para o esclarecimento da verdade, e o da fase de julgamento.

Com a edição do Código de Processo Penal de 1988, a legislação italiana trouxe um tratamento superficial da investigação desenvolvida pela defesa, ainda que em seus trabalhos preparatórios houvesse o aceno quanto à necessidade de codificação do tema de forma mais aprofundada ${ }^{5}$.

O grande mérito do novo Código foi o de romper com o clima inquisitorial que se instaurava na primeira fase do procedimento, implantando-se um sistema de vertente predominantemente acusatória.

4 "Certo, sono molto lontani i tempi in cui, come ricorda la relazione a testo di legge, la giurisprudenza del consiglio nazionale forense era costante nel ritenere che il colloquio puro e semplice del professionista con il testimone integrava l'illecito disciplinare perché il contatto con il testimone crea(va) una condizione obbiettiva dalla quale (potevano) derivare suggestioni e turbamenti dell'animo dei testimoni che ne (facevano) venir meno la libertà e l'obiettività necessarie, anche senza ipotizzare la possibilità di tentazioni per più deplorevoli comportamenti da parte del professionista. Ma quei tempi sono lontani non perché non sia più vera la situazione descritta dalla citata giurisprudenza del Consiglio nazionale forense, ma perché si è deciso di accettare il rischio." (MADDALENA, Marcello. Per la difesa libera di investigare facoltà e diritti, nessun dovere. Diritto e giustizia, Milano, n. 40, nov. 2000. p. 9).

5 "L'esigenza di una normativa che autorizzasse il difensore a svolgere attività in favore del proprio assistito e ne disciplinasse nella maniera più efficace l'esercizio, veniva avvertita già in sede di elaborazione del vigente codice di procedura penale." (SIRACUSANO, Delfino et al. Diritto processuale penale. Milano: Giuffrè, 2009. p. 159). 
Na versão aprovada da nova codificação houve apenas o reconhecimento da possibilidade de o defensor desenvolver a investigação e colher elementos servíveis à defesa, mas faltava uma normativa mais completa. Essa omissão tornava inidônea qualquer iniciativa investigatória, ainda que se encarasse a atividade como um reflexo do direito de cidadania ${ }^{6}$. Pontue-se que esse clima de anomia da investigação defensiva, apesar de desestimular o exercício da atividade, não impedia a sua realização, ainda que ela ocorresse de modo tímido e reprimido.

Em origem, o objetivo da investigação defensiva não era a colheita de elementos para a demonstração da responsabilidade do indiciado, ou ausência dela. Pensava-se na atividade de pesquisa defensiva como uma forma de subsidiar a atuação da defesa em juízo, inclusive para a própria tutela da liberdade, especialmente em casos de aplicação das medidas cautelares (misure cautelari), como explica Oliviero Mazza:

"As investigações defensivas, de acordo com o esquema de investigação da parte, destinavam-se apenas a preparar a estratégia probatória a ser implementada no julgamento e a não adquirir antecipadamente e unilateralmente provas a serem apresentadas ao juiz. O sistema foi caracterizado, no entanto, desde o início por uma assimetria conspícua: enquanto a investigação paralela do defensor foi relegada aos estreitos limites descritos acima, a atividade de investigação preliminar conduzida pelo promotor público, com a ajuda da polícia judiciária, foi objeto de um regulamento detalhado que testemunhou seu valor probatório mesmo fora da mesma fase processual". (tradução livre) ${ }^{7}$

6 "Nell'alveo di un simile modello d'attività esplorativa della difesa, anteriore all'instaurarsi del contraddittorio, in quanto istituzionalmente inidonea - al pari dell'indagine dell'accusa - a cristallizzare materiale probatorio, vantava un proprio naturale diritto di cittadinanza, anche a prescindere da ogni espressa previsione...” (DI CHIARA, Giuseppe. Le linee prospettiche del difendersi ricercando: luci e ombre delle nuove investigazioni difensive. $L a$ legislazione penale, Jovene, v. 22, n. 1-2, p. 1-28, gen./mar. 2002. p. 3).

7 "Le indagini difensive, secondo lo schema dell'inchiesta di parte, dovevano solo servire per predisporre la strategia probatoria da attuare nel processo e non per acquisire anticipatamente e unilateralmente elementi di prova da presentare al giudice. Il sistema era tuttavia caratterizzato, fin dall'inizio, da una vistosa asimmetria: mentre l'inchiesta parallela del difensore era relegata negli angusti confini appena descritti, l'attività di indagine preliminare 
O art. 38 do Decreto Legislativo 271, em sua redação originária, determinava que o defensor ou o investigador privado tinham a faculdade de desenvolver investigação destinada a colher elementos favoráveis ao seu defendido, além de arrolar pessoas que pudessem prestar informações servíveis à defesa, como um desdobramento do direito à prova previsto no art. 190 do Código de Processo penal.

Apesar da faculdade conferida pela lei, tratava-se, em verdade, de mera enunciação de princípios, pouco havendo de concretude ${ }^{8}$ na regra do art. 38 do Decreto Legislativo 271, especialmente no que diz respeito ao desenvolvimento da investigação, seus desdobramentos e à própria utilização do material produzido?.

O grande avanço do tema ocorre a partir da Lei 397, de 7 de dezembro de 2000. A nova lei revogou o art. 38 das normas de atuação do Código de Processo Penal (NAttCPP) e passou a regular a investigação defensiva na parte do Código destinada à fase pré-processual ${ }^{10}$.

condotta dal pubblico ministero, con l'ausilio della polizia giudiziaria, era oggetto di una dettagliata regolamentazione che ne testimoniava la valenza probatoria anche al di fuori della stessa fase procedimentale." (MAZZA, Oliviero. Fascicolo del difensore e utilizzabilità delle indagini defensive. In: REPERTORIO generale annuale della giurisprudenza italiana. Torino: UTET, 2002. 2 v. p. 1760).

8 “...la norma dell'art. 38, dunque, venne considerate 'pressoché inutile' dal momento che non precisava con quali contenuti ed in quali limite potesse concretamente estrinsecarsi l'attività investigativa del difensore e, quindi, non offriva all'interprete alcun criterio positivo per costruire gli strumenti concettuali operativi (così Cristiani)." (SIRACUSANO, Delfino et al. Diritto processuale penale. Milano: Giuffrè, 2009. p. 160).

9 CONSO, Giovanni; ILLUMINATI, Giulio. Commentario breve al codice di procedura penale. Milano: CEDAM, 2014. p. 1657.

10 "La volontà di rafforzare la funzione difensiva nella fase preprocessuale è manifestata, innanzitutto, non solo dalla collocazione nel corpo del codice del diritto ad effettuare investigazioni (art. 327 bis), ma anche dalla creazione di un titolo ad hoc (titolo VI bis: art. 391 bis - 391 decies) dedicato all'intera disciplina dalla conseguente abrogazione dell'art. 38 delle disposizioni di attuazione: è evidente che la scelta operata si ispira ad una completa equiparazione tra accusa e difesa, il cui scopo finale è, quindi, l'introduzione di un sistema parallelo tra le indagini svolte dal pubblico ministero e quelle condotte dal difensore. L'analiticità con cui si è proceduto mostra inoltre una particolare attenzione volta ad evitare, da un lato, che il colloquio e la ricezione di informazioni di trasformino in uno strumento per conoscere le strategie 
Essa lei destacou um título específico para a chamada Investigazioni Difensive (Investigações Defensivas). Assim que editado o diploma, houve um intenso movimento de recepção das novas disposições, especialmente sob a perspectiva do processo justo.

O propósito da investigação defensiva foi o de tornar a atuação da defesa mais dinâmica, deixando a defesa de desempenhar um papel de mera resistência, passando a incorporar um perfil de atuação proativo a partir da atividade desempenhada por toda a equipe defensiva.

O perfil dinâmico que se esperava da defesa no exercício de uma atividade de investigação nada mais era do que o desdobramento das normas convencionais que asseguravam ao imputado o direito a uma defesa técnica e à produção probatória ${ }^{11}$.

Hoje, pela leitura do art. 327-bis do CPP italiano, o defensor está autorizado a buscar elementos em favor do seu defendido, em qualquer grau ou fase do processo, para eventual revisão criminal ou até mesmo na seara da execução penal.

Sempre houve uma premente exigência de adaptação do Código de Processo Penal italiano, buscando estabelecer um equilíbrio entre a acusação e a defesa, além do enfrentamento relativo à problemática dos atos unilateralmente colhidos pelo Ministério Público e pela Polícia Judiciária $^{12}$.

A reforma da investigação defensiva deixou claro o propósito de romper o monopólio da atividade investigativa concentrado nas mãos do Ministério Público, especialmente quando considerado o fato de que

processuali messe in atto dal pubblico ministero e lo sviluppo delle indagini preliminari, dall'altro a tutelare non solo il soggetto da esaminare, ma il difensore stesso dalle potenziali pressioni dell'assistito." (PRIOTTI, Giuliana. Le investigazioni difensive: la conclusione di una storia infinita. Questione Giustizia, Roma, n. 1, gen./feb. 2001. p. 56).

11 "Ciò, nonostante, all'interno dei testi sopra citati è possibile ritrovare passaggi significativi che descrivono il diritto di difesa in termini attivi e dinamici e non come mera attività di critica dell'ipotesi d'accusa, che, dunque, possono giustificare l'affermazione secondo cui la difesa è legittimata ad esperire le investigazioni ritenute utili alla posizione del proprio assistito.” (VELANI, Luigi Gino. Le investigazioni preventive. Milano: Giuffrè, 2012. p. 9).

12 PRIOTTI, Giuliana. Le investigazioni difensive: la conclusione di una storia infinita. Questione Giustizia, Roma, n. 1, gen./feb. 2001. p. 44. 
a inatividade do órgão acusatório na busca de elementos favoráveis ao imputado não acarretava nulidade do procedimento, visto que a defesa poderia exercer a sua própria investigação.

Nota-se, portanto, que a aparente anomia quanto ao tema da investigação defensiva não foi um fator a obstar o seu exercício. A exigência de lei se tornou necessária para trazer mais segurança à atividade, mas nunca como uma condição.

Aqui, então, revela-se que a edição de um conjunto de normas sobre a investigação defensiva tornou-se necessário para trazer maior segurança ao profissional da defesa técnica, além de buscar estimular a atividade investigativa de viés defensivo.

\section{I.2 - A InVEStigaÇÃo CRIMINAL defensiva nos Estados Unidos da AmÉrICA}

Diferentemente da Itália, os Estados Unidos não possuem um diploma legal com seção normativa destinada à disciplina da investigativa defensiva, mas encontramos uma série de preceitos destinados ao exercício da função de defesa no processo penal que tratam dos atos de investigação.

Rememore-se também que uma das características marcantes do sistema processual norte-americano guarda relação direta com a repartição de ônus e a produção da prova, já que se trata de um sistema marcantemente adversarial.

O grande mérito do direito norte-americano é o de contemplar o momento de Discovery ou Disclosure, como também denomina o Direito Inglês, que se qualifica como uma fase pré-processual de aferição dos elementos de provas referentes aos fatos da causa, aplicada no direito processual civil. Faça-se a advertência de que a Disclosure do direito inglês não se confunde com o duty to disclosure dos Estados Unidos.

A edição das Federal Rules of Civil Procedure trouxe profunda modificação na estrutura dos litígios civis. O objetivo da Discovery era afastar do processo civil o fator surpresa e a chamada teoria esportiva, segundo a qual quem tivesse o melhor desempenho ganhava. Podese dizer que a Discovery corresponde a um procedimento probatório 
extrajudicial ou, como denominaremos nesta tese, um procedimento de compartilhamento de informações ${ }^{13}$.

Trata-se de um modo de fornecimento recíproco de informações, apesar de não constituir, como regra geral, um direito assegurado pela Constituição norte-americana ${ }^{14}$. De acordo com as normas processuais de cada Estado, que recebem tratamentos jurídicos diversos ${ }^{15}$, as partes fornecerão todas as provas de que dispõem, inclusive tomando depoimentos pessoais, sem a interveniência do Poder Judiciário ${ }^{16}$.

Não se trata, todavia, de uma abertura absoluta de provas, visto que determinadas informações são imunes à fase de descoberta, a exemplo de questões que envolvam o sigilo profissional (relação de confidencialidade entre advogado e cliente, médico e paciente etc.) e determinados documentos (histórico infracional na adolescência, por exemplo).

O objetivo da fase de descoberta é evitar o fator surpresa ${ }^{17}$ que se instala no processo, ao mesmo tempo em que incentiva a conciliação entre as partes, evitando-se o ajuizamento de demandas perante o Judiciário. Ao exibir o material probatório de que dispõe a parte,

13 GRIMM, Paul W; FAX, Charles S ; SANDLER, Paul Mark. Discovery problems and their solutions. Chicago: American Bar Association, 2014. P. 131.

14 "As stated by the US Supreme Court in Wheatherford v. Bursey, 429 U.S. 545, 554 (1977), 'There is no general Constitutional right Discovery in criminal cases." (PAPERNO, Jill. Representing the accused. Minnesota: Aspatore, 2012. p. 132).

"You cannot rely on general knowledge of what may constitute Discovery, since Discovery varies tremendously from state to state. For example, some states such as Florida, provide defense counsel with the opportunity to depose in adverse witnesses, while other states do not." (PAPERNO, Jill. Representing the accused. Minnesota: Aspatore, 2012. p. 133).

16 "Una parte puede solicitar la declaración de la otra o la exhibición de documentos que estén em poder de la parte contraria. Y todo ello sin la necesaria aprobación del tribunal. Los abogados toman la iniciativa por completo en esta fase del proceso americano, trasladando las peticiones de interrogatório o exhibicion." (PUIGVERT, Silvia Pereira. La exhibición de documentos y soportes informáticos en el proceso civil. Navarra: Arazandi, 2013. p. 236).

17 "Se fundamenta en el principio de evitar juzgamientos sorpresivos (trial by surprise) y se basa en la experiencia del mismo instituto en materia civil. Muchos Estados tiene legislado el tema. Otros lo mantienen como cuestión discrecional del tribunal." (HENDLER, Edmundo S. Derecho penal y procesal penal de los estados unidos. Buenos Aires: Ad-Hoc, 2006. p. 189). 
torna-se possível medir as consequências do processo, principalmente se o direito da parte é bom.

Com o avanço do instituto no campo do direito processual civil note-se que a doutrina aponta muitos desvirtuamentos na Discovery - tornou-se inevitável que o processo penal também incorporasse uma disciplina de compartilhamento e transparência prévia do material probatório.

Assim, dentro da perspectiva de um sistema adversarial, em que a iniciativa da condução do processo fica a cargo das partes, assumindo o juiz uma postura neutra ${ }^{18}$, o ordenamento jurídico se preocupou com a existência de uma regra de transparência na revelação das provas que as partes dispõem a fim de se alcançar a verdade no processo ${ }^{19}$.

Apesar de não haver um precedente da Suprema Corte única e especificamente destinado à atividade de investigação criminal defensiva, podemos apontar uma importante premissa definida no caso Strickland vs. Washington, quando a Corte decide que a investigação realizada pelo defensor é um elemento essencial para a caracterização de uma defesa efetiva ${ }^{20}$.

18 "By adversary I mean a system of adjudication in which procedural action is controlled by the parties and the adjudicator remains essentially passive. In the fact-finding domain, this implies that the litigants and their counsel decide what facts shall be subject to proof. It further implies that litigants and their counsel are entrusted with seeking evidentiary material, preparing it for use at trial, and presenting it in court.” (DAMAŠKA, Mirjan R. Evidence law adrift. London: Yale University Presse, 1997. p. 74).

19 "Por adversarial quero dizer um sistema de adjudicação no qual a ação processual é controlada pelas partes e o adjudicador permanece essencialmente passivo. No domínio da apuração dos fatos, isto implica que os litigantes e o seu advogado decidam quais os fatos que devem ser sujeitos a prova. Implica ainda que os litigantes e seus advogados são encarregados de buscar material probatório, preparando-o para uso no julgamento e apresentando-o em tribunal. (tradução livre)

"Não há mais espaço para a chamada carried in the dark que consistia no conjunto de manobras de uma parte visando surpreender a outra e desse modo conquistar uma vantagem estratégica nos debates. A forma usual de empregar o carried in the dark era por intermédio da introdução dos meios de provas desconhecidos da parte contrária (unfair surprise), que ignorava sue modo de aquisição (a fonte das provas)." (PRADO, Geraldo. Prova penal e sistema de controles epistêmicos. São Paulo: Marcial Pons, 2014. p. 53).

20 "A importância histórica do caso Strickland para o tema central em digressão - investigação criminal defensiva - não é tanto o resultado do julgamento, e sim o fato de a Corte ter reconhecido expressamente que o dever de 
Diogo Malan bem registra as críticas deduzidas ao citado precedente, pautadas no fato de que as suas premissas mais atrapalham a compreensão do problema, por deixar em aberto temas como os deveres éticos e direitos fundamentais dos acusados ${ }^{21}$.

No plano normativo, a par das normas destinadas à Discovery e ao Duty to Disclosure, podemos apontar as regras da American Bar Association relativas à função defensiva (Criminal Justice Standards for the Defense Function), com especial enfoque para a sua parte IV, que trata da investigação e da preparação (Investigation e preparation) ${ }^{22}$.

A investigação criminal defensiva no sistema jurídico norte-americano conta com um quadro que envolve a participação do advogado, de um investigador privado, de peritos e assistentes. A relação de sigilo entre defensor e cliente prevista no caso Upjohn Co. v. United States também é estendida aos demais integrantes do quadro defensivo por força do caso United States v. Kovel ${ }^{23}$.

investigação (duty to investigate) é um dos corolários lógicos do dever de proporcionar ao acusado uma defesa técnica efetiva." (MALAN, Diogo Rudge. Investigação defensiva no processo penal. Revista Brasileira de Ciências Criminais, São Paulo, v. 20, n. 96, maio/jun. 2012. p. 282).

“Também se critica a premissa de que o único propósito do processo penal de partes é viabilizar o confronto significativo da prova de acusação em Juízo, assegurando a credibilidade do veredito proferido. Argumenta-se que esse modelo processual também serve a outros propósitos, tais como tutelar os direitos fundamentais do acusado. Nesse sentido, se critica o fato de os casos Cronin e Strickland não fornecerem quaisquer deveres éticos mínimos que devem pautar a atuação do defensor técnico criminal, a fim de que ela possa ser considerada conforme o right to counsel da 6.a Emenda. Por derradeiro, se argumenta que os critérios vagos e imprecisos delineados nesses dois precedentes jurisprudenciais ensejaram uma sucessão de decisões judiciais casuísticas, imprevisíveis e heterogêneas entre si." (MALAN, Diogo Rudge. Investigação defensiva no processo penal. Revista Brasileira de Ciências Criminais, São Paulo, v. 20, n. 96, maio/jun. 2012. p. 282). AMERICAN BAR ASSOCIATION. Section of criminal justice. Criminal justice standards for the defense function: fourth edition, Illinois, June, 2016. Disponível em: <https://www.americanbar.org/groups/criminal_justice/ standards/DefenseFunctionFourthEdition-TableofContents/>. Acesso em: 27 nov. 2019..

23 "As a general rule, the communication between defense counsel and his agents retained to assist in the defense of a criminal case is protected under the attorney-client privilege and work product doctrine. The extension of the 
Sob um prisma teórico, a doutrina costuma apontar a seguinte metodologia para a condução de uma investigação criminal defensiva no sistema norte-americano: 1 - revisão dos materiais fornecidos pelo procedimento da Discovery (relatórios policiais, laudos de local, laudos periciais e informações das vítimas e testemunhas); 2 - entrevista inicial do imputado; 3 - exame do local do crime com registro esquemático e fotográfico; 4 - coleta de informações sobre o perfil das vítimas e testemunhas; 5 - confecção de relatório da investigação defensiva ${ }^{24}$.

Não há, todavia, um diploma específico sobre o tema, mas a soma de precedentes que tratam da atividade defensiva (direito à defesa técnica e dever de compartilhamento pela acusação, por exemplo), princípios e regras sobre a Discovery, além dos Standards da ABA (American Bar Association) sobre atividade defensiva e investigação.

Percebemos, portanto, que em dois países de estrutura completamente distinta (common law e civil law) contemplam mecanismos de permissão à busca de elementos de formação do convencimento pela defesa técnica nos mais variados estágios da persecução.

Desse modo, parece-nos pertinente, agora, investigar até que ponto o ordenamento jurídico brasileiro alberga espaço para a investigação criminal defensiva.

privilege to agents of defense counsel is commonly identified as the Kovel Privilege, deriving its name from the decision in the United States v. Kovel, 296 F.2d 918 (2d Cir. 1961). The privilege is subject to all fo the customary limitations of the attorney-client privilege." (PERRON, Brandon A. Uncovering reasonable doubt. Nebraska: Morris Publishing, 1998. p. 4-3).

"The following components of investigative procedure should be used as a basic guide and formula when conducting a criminal defense investigation. The procedures can be amended or expanded to suit the individual needs of each case. The procedure is designed to apply effectively to all criminal defense cases from simple battery to first degree murder: 1 . Investigative Review of the discovery file; police reports, victim/witness statements, crime scene examinations, lab reports, etc.; 2. Initial Defendant Interview; 3. Crime Scene Examination, Diagram \& Photography; 4 - Victim/Witness Background Investigation; 5 - Witness Location, Interviews and Statements; 6 - Report of Investigation \& Testifying. The criminal defense investigator will not always be required to pursue all of the procedures outlined within this text. However, he should fully understand each and be able to effectively accomplish each task if called upon to do so." (PERRON, Brandon A. Uncovering reasonable doubt. Nebraska: Morris Publishing, 1998. p. 1-5). 


\section{I - O Potencial do Sistema Jurídico Brasileiro no Campo da Investigação Criminal Defensiva}

\section{II.1 - SUPORTE NORMATIVO PARA A INVESTIGAÇÃO DEFENSIVA}

Alçados ao nível constitucional e convencional, a ampla defesa e o contraditório previstos no art. $5^{\circ}$, LV, da CRFB representam os elementos-chave para o embasamento da investigação criminal defensiva, os seus pilares de sustentação no sistema jurídico interno.

O direito à prova assume a morfologia de direito fundamental pelo reconhecimento dos princípios supramencionados e também pela garantia de inadmissibilidade das provas obtidas por meios ilícitos. Como bem pontua Vitor de Paula Ramos:

A fundamentalidade formal do direito à prova pode ser localizada em dois incisos do art. 5.o da CF/1988. Primeiramente, no inc. LVI, uma vez que, proíbida a admissão das provas ilícitas, permitida está a admissão das provas lícitas. Ainda, no inc. LV, em que, ao garantir o contraditório e a ampla defesa, o legislador constitucional explicitamente faz referência à asseguração dos meios inerentes a essa; entre tais meios inerentes, está, por óbvio, o direito à prova. A fundamentalidade material da prova está intrinsecamente ligada à verdade e à importância dessa para qualquer relação jurídica. Não é aqui a sede adequada para que se reproduzam as diversas discussões doutrinárias sobre o tema. Bastará dizer que adotamos como premissa que a verdade é objetiva (no sentido de que não é determinada por um sujeito) e que se deve supor uma verdade por correspondência (no sentido de que independe de qualquer consenso ou coerência narrativa: a neve é branca somente se a neve é branca). ${ }^{25}$

Em decorrência dos compromissos e tratados firmados pelo Brasil no plano internacional, especialmente os diversos instrumentos de proteção dos direitos humanos, torna-se possível identificar outra fonte de suporte normativo para o exercício da defesa técnica e da atividade

25 RAMOS, Vitor de Paula. Direito fundamental à prova. Revista de Processo, São Paulo, v. 38, n. 224, p. 41-61, out. 2013. p. 44. 
investigativa defensiva, esta última como corolário do direito à prova assegurado a todo imputado na investigação e no processo criminal.

A Convenção Americana de Direitos Humanos prevê em seu art. $8^{\circ}$, itens 1 e 2 , ' $b$ ', 'c', ' $d$ ', ' $e$ ' e 'f', as garantias judiciais mínimas para o acusado e dali se extrai o direito à atividade probatória, especialmente quando são assegurados a defesa técnica, o tempo e os meios necessários para preparação da defesa.

A menção à defesa técnica e aos meios para a preparação da defesa compreende não só a presença de um defensor com capacidade para exercer a representação na fase investigatória e no processo penal, mas também a disponibilização dos recursos e meios de provas admitidos no ordenamento jurídico.

No Pacto Internacional de Direitos Civis e Políticos semelhantes direitos estão previstos no art. $14^{\circ}$, itens 1 , 2 e 3 , alíneas ' $b$ ', ' $d$ ' e ' $e$ ', na mesma estruturação da norma americana, assegurando-se a todo imputado o direito à defesa técnica e o tempo e meios necessários ao exercício da defesa.

Por trás do direito a um defensor e da garantia de tempo e dos meios necessários para o exercício da defesa, insere-se a possibilidade de produzir provas na relação processual ${ }^{26} \mathrm{e}$, consequentemente, o direito ${ }^{27}$ à realização da busca e coleta de informações de interesse da defesa.

26 "O direito à prova não encontra previsão expressa na Constituição Federal, podendo ser extraído no art. 5.o, LV no que tange à sua intrínseca ligação com o contraditório e a ampla defesa. No âmbito internacional pode-se citar a Convenção Americana de Direitos Humanos, incorporada pelo Dec. 678/1992, que estabelece, no art. 2.o, f, o "direito da defesa de, em plenas condições de igualdade com a acusação, inquirir as testemunhas presentes no Tribunal e de obter o comparecimento, como testemunhas ou peritos, de outras pessoas que possam lançar luz sobre os fatos", bem o Pacto Internacional de Direitos Civis e Políticos de Nova Iorque, incorporado pelo Dec. 592/1992, que traz previsão análoga no art. 14, § 3.o, e" (NARDELLI, Marcella Alves Mascarenhas. O direito à prova e à não autoincriminação em uma perspectiva comparada entre os processos civil e penal. Revista de Processo, São Paulo, v. 40, n. 246, p. 171-198, ago. 2015. p. 180).

27 "En el terreno de la admisión de pruebas, que las partes tengan el derecho a probar un hecho significan que tienen la facultad de presentar todos los medios de prueba relevantes y admisibles para apoyar su versión de los hechos en litigio. Para la parte que alega un hecho, esto significa que debe tener la posibilidad de presentar todas las pruebas positivas con las que cuente; para 
A investigação defensiva, nas palavras de André Mendes, é: "garantia fundamental do imputado, inerente a um processo de partes, na medida em que constitui instrumento para a concretização dos direitos constitucionais de igualdade e defesa" ${ }^{28}$.

Francisco da Costa Oliveira, quando analisa a investigação criminal em Portugal, afirma com muita propriedade:

"não existem no nosso ordenamento jurídico quaisquer limitações à actividade de investigar por conta própria ou por intermédio de terceiros, pelo que podemos partir da afirmação de um princípio geral da livre investigação dos factos coincidentes com alguns dos direitos, liberdades e garantias constitucionalmente consagrados...."29.

Em certo ponto, há um receio de que a investigação criminal defensiva não tenha espaço no Brasil por conta da ausência de regras que disciplinem o seu modo de realização. Pensar dessa forma seria negligenciar o conteúdo do princípio do devido processo legal e efetuar uma errônea leitura da ampla defesa, do contraditório, do direito à atividade probatória e da própria isonomia.

Quando se leva em conta que as frágeis bases da investigação direta do Ministério Público lhe permitem colher fontes de prova na qualidade de parte da relação processual, pensar que a defesa não possa ter iniciativa investigativa fragiliza a isonomia.

la parte contraria, supone que debe tener la oportunidad de presentar todas las pruebas contrarias o negativas de que disponga en relación con esos hechos. Desde el punto de vista de las normas relativas a la admisión de pruebas, este problema se debe resolver invocando simplemente al principio de relevancia (véase supra apartado 1): deben ser admitidas todas las pruebas positivas y negativas o contrarias relevantes. Las partes no pueden pretender que se admitan pruebas irrelevantes, pero se les debería permitir cualquier medio de prueba relevante" (TARUFFO, Michele. La prueba. Madrid: Marcial Pons, 2008. p. 57).

MACHADO, André Augusto Mendes. Investigação criminal defensiva. São Paulo: Revista dos Tribunais, 2010. p. 119. 
A ampla defesa representa o direito de empregar todos os meios e recursos necessários ao exercício do direito de defesa ${ }^{30}$ e essa assertiva tem uma razão de ser dentro do sistema jurídico ${ }^{31}$.

Um processo justo depende, em grande parte, da disposição de meios necessários para que a pessoa submetida a uma imputação penal possa participar do processo pessoalmente (autodefesa) ${ }^{32}$ e ao mesmo tempo ter ao seu lado um profissional encarregado de manusear os instrumentos previstos no ordenamento jurídico (defesa técnica), garantindo-se a desejada paridade de armas na relação processual penal ${ }^{33} \mathrm{e}$ um resultado que melhor atenda aos interesses do imputado ${ }^{34}$.

30 "As partes ou os interessados na administração da Justiça devem ter o direito de apresentar todas as alegações, propor e produzir toda as provas que, a seu juízo, possam militar a favor do acolhimento da sua pretensão ou do não acolhimento da postulação do seu adversário. Esse direito abrange tanto o direito à auto-defesa quanto à defesa técnica por um advogado habilitado, e também o direito a não ser prejudicado no seu exercício por obstáculos alheios à sua vontade ou pela dificuldade de acesso às provas de suas alegações. A ampla defesa é por si mesma uma garantia genérica que se concretiza em muitas outras, sendo impossível delimitar aprioristicamente todo o seu alcance e, portanto, dela estarei tratando em muitos momentos no curso do presente estudo." (GRECO, Leonardo. Garantias fundamentais do processo: o processo justo. In: . Estudos de Direito Processual. Campos dos Goytacazes: Editora Faculdade de Direito de Campos, 2005. p. 39).

31 "A garantia da ampla defesa envolve, modernamente, tríplice enfoque: 'o direito à informação, a bilateralidade da audiência e o direito à prova, legitimamente obtida ou produzida." (SAAD, Marta. O direito de defesa no inquérito policial. São Paulo: Revista dos Tirbunais, 2004. (Coleção Estudos de Processo Penal Prof. Joaquim Canuto Mendes de Almeida, v. 9). p. 215).

32 "O direito de defesa apresenta-se bipartido em (a) direito à autodefesa; e (2) direito à defesa técnica. $\mathrm{O}$ direito à autodefesa é exercido pessoalmente pelo acusado, que poderá diretamente influenciar o convencimento do juiz. Por sua vez, o direito à defesa técnica é exercido por profissional habilitado, com capacidade postulatória e conhecimentos técnicos, assegurando assim a paridade de armas entre a acusação e defesa.” (BADARÓ, Gustavo. Processo Penal. 4. ed. São Paulo: Revista dos Tribunais, 2016. p. 58).

33 "Ora, tudo isso está implícito nos meios e recursos essenciais ao direito de defesa, podendo parecer redundância, portanto, que a Constituição ainda impusesse, como garantia fundamental, a instrução contraditória.” (MARQUES, José Frederico. Elementos de direito processual penal. Campinas: Bookseller, 1998. 4 v. V. 2. p. 87).

34 "A cláusula da ampla defesa deve ser dotada do atributo da efetividade, entendida como idoneidade instrumental para atingir seu objetivo precípuo: a 


\section{II.2 - A AMPLA DEFESA E CONTRADITÓRIO COMO PRINCÍPIOS NORTEADORES}

A perspectiva do contraditório representa a possibilidade de a defesa exercer a influência em torno da interpretação fática que lhe seja mais favorável, realizando atividade probatória com essa finalidade ${ }^{35}$.

A atividade probatória se insere nesse contexto, como a forma de materialização da ampla defesa e o instrumento de exercício do contraditório, fazendo com que o plano abstrato das alegações encontre eco de concretude nos autos do processo ${ }^{36}$.

$\mathrm{Na}$ atividade de investigação defensiva, essa premissa também é verdadeira. O papel da defesa técnica é arrecadar informações e elementos que possam direcionar o exercício da resistência à pretensão acusatória e

melhora da situação jurídica do acusado. Nas hipóteses em que o defensor do acusado é negligente ou imperito, desperdiçando sucessivas oportunidades processuais a ponto de diminuir as chances de melhora da situação jurídica do seu constituinte, esvazia-se o conteúdo essencial da garantia constitucional da ampla defesa, que deixa de ter esse atributo da efetividade." (MALAN, Diogo Rudge. Defesa penal efetiva. Ciências Penais: Revista da Associação Brasileira de Professores de Ciências Penais, São Paulo, v. 3, n. 4, p. 253-277, jan./jun. 2006. p. 253-277).

35 "Reconhecido o processo como método epistêmico para aquisição de conhecimento, é possível dar um passo à frente e qualificar a cognição adequada como consectário lógico e necessário do contraditório e, portanto, como parte do arcabouço garantístico do processo justo. Se o meio para democratizar o ato jurisdicional é o contraditório, viabilizando o direito da parte de influir na decisão judicial, de participar na construção do conhecimento-julgamento no processo, isso somente vai ocorrer se esse processo tiver estrutura cognitiva capaz para tanto. A cognição é, portanto, uma garantia instrumental do contraditório, que permite a adequação da fisiologia do processo para a eficaz produção de conhecimento." (ARAÚJO, José Aurélio de. Cognição sumária, cognição exaustiva e coisa julgada. São Paulo: Revista dos Tribunais, 2017. p. 79).

36 "Salienta-se, assim, o direito à prova como aspecto de particular importância no quadro do contraditório, uma vez que a atividade probatória representa o momento central do processo: estritamente ligada à alegação e à indicação dos fatos, visa ela a possibilitar a demonstração da verdade, revestindo-se de particular relevância para o conteúdo do provimento jurisdicional. O concreto exercício da ação e da defesa fica essencialmente subordinado à efetiva possibilidade de se representar ao juiz a realidade do fato posto como fundamento das pretensões das partes, ou seja, de estas poderem servir-se das provas." (GRINOVER, Ada Pellegrini; FERNANDES, Antonio Scarance; GOMES FILHO, Antonio Magalhães. As nulidades no processo penal. 9. ed. São Paulo: Revista dos Tribunais, 2006. p. 137). 
sugerir a proposição das provas na relação processual, permitindo que ambas as partes tenham o controle e a previsibilidade de suas ações no processo.

Não é por outra razão que o Estatuto da OAB (Lei n. 8906/1994) e a Lei Orgânica da Defensoria Pública (Lei Complementar n. 80/1994) asseguram ao indiciado a assistência jurídica desde o inquérito policial e até após o trânsito em julgado da ação penal, de modo que o acompanhamento da coleta de elementos de formação do convencimento seja a mais completa possível ${ }^{37}$.

É a partir da intervenção defensiva na fase preliminar que o advogado ou membro da Defensoria Pública terão o pleno controle da atividade de defesa e poderão aprimorar o seu modo de agir na tutela de interesses do imputado.

O indiciado no inquérito policial não pode ser tratado como mero objeto da investigação. Objeto é tão somente o fato a ser apurado, sendo o investigado verdadeiro sujeito de direitos, com a certeza de que um rol de garantias ser-lhe-á assegurado ${ }^{38}$.

Enxergar o contraditório apenas como a possibilidade de ciência e reação é uma visão reducionista do princípio. Se é fato que o contraditório possui essa vertente da participação na relação processual, a doutrina moderna também reconhece a possibilidade de se exercer a influência sobre o juiz na tomada da decisão como uma terceira característica do princípio ${ }^{39}$.

37 "Justamente por ser o inquérito uma etapa importante para a obtenção de meios de provas, inclusive com atos que depois não mais se repetem, o acusado deve contar com assistência de defensor já nessa fase preliminar, preparando adequada e tempestivamente sua defesa, substancial de conteúdo” (SAAD, Marta. O direito de defesa no inquérito policial. São Paulo: Revista dos Tirbunais, 2004. (Coleção Estudos de Processo Penal Prof. Joaquim Canuto Mendes de Almeida, v. 9). p. 200-201).

38 "Em verdade, o envolvido em inquérito policial deve ser reconhecido como sujeito ou titular de direitos, sujeito do procedimento e não apenas sujeito ao procedimento, verdadeiro titular de direitos que dentro dele exerce. O indivíduo é, aliás, sujeito e titular de direitos sempre, não importa em que estágio o procedimento se encontre. Os direitos e as garantias constitucionais não têm limites especiais nem obedecem a procedimentos, simplesmente devem ser obedecidos sempre." (SAAD, Marta. O direito de defesa no inquérito policial. São Paulo: Revista dos Tribunais, 2004. (Coleção Estudos de Processo Penal Prof. Joaquim Canuto Mendes de Almeida, v. 9). p. 200-201).

39 “Tal visão se encontra consentânea à concepção forte de contraditório, traduzida no direito de influência e no dever de debate endoprocessual, elementos preordenados à apresentação de argumentos racionais, tudo com vistas 
Não basta que a parte se manifeste no processo. Ela tem o direito de contribuir, cooperar na busca da decisão de mérito e influir no convencimento do juiz e na interpretação das normas discutidas na lide, em autêntico contraditório participativo.

Como bem registra Daniel Mcconkie em seu estudo sobre a Discovery, não faz sentido reconhecer que o juiz e o jurado tenham o direito de acessar todas as provas para a formação do convencimento e negar esse acesso ao imputado. Somente com informação ampla é que o acusado e seu defensor podem fazer juízos de valor a respeito das medidas, atos e renúncias a serem tomadas no procedimento criminal:

Da mesma forma que um júri precisa de informações expansivas para julgar adequadamente a culpa e um juiz de primeiro grau tem a necessidade de mais informações para pronunciar uma sentença razoável, os réus precisam de informações expansivas para se declarar culpados e concordar com uma sentença, ou pelo menos nos contornos de uma sentença. Antes de se declararem culpados, eles precisam ter acesso tanto a evidências que os beneficie ou prejudique que estejam em poder do promotor. (tradução livre $)^{40}$

O duty to disclosure norte-americano e a indagine difensiva italiana contribuem decisivamente para a construção de uma boa defesa, ao permitirem que o defensor e o imputado possam ter um panorama dos elementos que recaem em seu desfavor e, diante dessa conjuntura, realizar

a influir na convicção do órgão julgador e dos demais sujeitos no debate relativo à resolução da questão de direito. Repise-se, pois, que o contraditório não pode mais ser analisado tão somente como mera garantia formal de bilateralidade da audiência, mas sim como uma possibilidade de influência sobre o desenvolvimento do processo e sobre a formação de decisões racionais e pretensamente corretas, com inexistentes ou reduzidas possibilidades de surpresa." (CAVACO, Bruno de Sá Barcelos. Desjudicialização e resolução de conflitos. Curitiba: Juruá, 2017. p. 98).

40 "In the same way that a trial jury needs expansive information to properly adjudicate guilt and a trial judge needs even more information to pronounce a reasonable sentence, defendants need expansive information to intelligently plead guilty and agree to a sentence, or at least the contours of a sentence. Before they plead guilty, they need access to both exculpatory and inculpatory evidence in the prosecutor's possession." (MCCONKIE, Daniel S. Structuring pre-plea criminal discovery. The Journal of Criminal Law \& Criminology, Evanston, v. 107, n. 1, p. 1-34, May 2017. p. 7). 
diligências no interesse da defesa, as quais servirão para robustecer a atividade probatória realizada na instrução processual.

Apesar de pouco explorado no processo penal, o aspecto da influência decorrente do contraditório é essencial para compreendermos a utilidade da investigação defensiva ${ }^{41}$, já que a atividade probatória não se resume apenas ao ato de produção, mas também ao de interferir na sua valoração.

Torna-se natural concluir que, por trás da ampla defesa e do contraditório, é possível desdobrar uma série de direitos e garantias, dentre as quais a possibilidade de investigação defensiva como substrato do direito à produção probatória, esse último derivado do devido processo legal ${ }^{42} \mathrm{e}$ da paridade de $\operatorname{armas}^{43}$.

O contraditório também exerce seu papel axiológico na investigação criminal defensiva na medida em que a pesquisa desempenhada pela defesa nada mais é do que uma resposta à atividade persecutória punitiva ${ }^{44}$.

${ }^{41}$ Quando aborda a questão do objeto do contraditório Fazzalari explica: "È costituito da questioni relative alle stesse attività processuali: se siano ammisibili (rectius, leciti o doverosi), pertinenti, utili uno o più atti da svolgere (ad esempio, nel processo giurisdizionale civile, la questione dell'ordine d'integrazione del contradittorio; quella dell'ammissione di una prova; quella della dichiarazione d'invalidità di un atto processuale; della sua rinnovazione). Anche le questioni cosidette di merito concernono il compimento di un atto processuale: precisamente dell'atto finale, del provvedimento (ancora nel processo civile, la questione di merito culminante è se il giudice debba emmetere il provvedimento giurisdizionale richiesto, o rifiutarlo." (FAZZALARI, Elio. Instituzioni di diritto processuale. 6. ed. Milano: CEDAM. 1992. p. 87-88).

42 "Por consiguiente, el derecho a presentar todos los medios de pruebas relevantes que estén al alcance de las partes es un aspecto esencial del derecho al debido proceso y debe reconocerse que pertenece a las garantías fundamentales de las partes." (TARUFFO, Michele. La prueba. Madrid: Marcial Pons, 2008. p. 56).

43 "O direito fundamental à investigação defensiva, portanto, pode ser duplamente fundamentado: (a) no direito à prova defensiva, na medida em que o seu exercício em Juízo pressupõe prévia atividade investigativa; (b) na garantia da paridade de armas." (MALAN, Diogo Rudge. Investigação defensiva no processo penal. Revista Brasileira de Ciências Criminais, São Paulo, v. 20, n. 96, maio/jun. 2012. p. 290).

44 "A prova passa a ser um dos componentes do direito de defesa, o direito de defender-se provando, que não se exaure no direito de propor a sua produção, 
Em síntese de tudo o que foi exposto, o direito à prova é verdadeiro desdobramento dos princípios da ampla defesa e do contraditório ${ }^{45}$ e a investigação criminal defensiva se insere como um procedimento defensivo dirigido à atividade probatória e com propósitos próprios a serem avaliados pela defesa técnica e com momentos não estanques para sua realização.

\section{II.3 - A dEFINIÇÃO DA INVESTIGAÇ̃̃o DEFENSIVA NO BRASIL}

Estamos, na verdade, em um momento normativo de sombras, em que cabe ao legislador definir os estreitos limites da atuação defensiva com vistas à sua própria segurança, evitando-se a incidência de figuras típicas como nos casos em que a defesa esteja agindo de boa-fé, sujeitando-se a transtornos derivados de equívocos interpretativos por parte dos agentes estatais.

No entanto, essa zona de penumbra não representa um obstáculo à realização da investigação defensiva, mas apenas um alerta a quem a realiza, daí a necessidade de se enxergar uma capacidade normativa plural. Ainda que anseie pele regulamentação a nível legislativo, os órgãos de defesa podem avançar seus primeiros passos no trato do tema.

mas se completa com o direito de produzir todas as provas que potencialmente tenham alguma relevância para o êxito da postulação ou da defesa.

Mas a parte não pode ter prejudicado o seu acesso à tutela jurisdicional em razão da dificuldade de produzir a prova dos fatos que a ela interessam, em razão das regras que distribuem os ônus da prova. A doutrina e a jurisprudência vêm aconselhando, nesses casos, a inversão do ônus da prova, como meio de restabelecer o equilíbrio entre as partes no acesso à tutela jurisdicional efetiva, repudiando as chamadas provas diabólicas, ou de produção impossível, que põem uma das partes em indevida posição de vantagem, incompatível com a garantia do contraditório." (GRECO, Leonardo. Garantias fundamentais do processo: o processo justo. In: . Estudos de Direito Processual. Campos dos Goytacazes: Editora Faculdade de Direito de Campos, 2005. p. 44).

"A jurisprudência brasileira é tranquila nesse sentido, falando na imprescindibilidade de se conferirem a ambas as partes todos os recursos para o oferecimento da matéria probatória. E, se tal não ocorrer, fala a jurisprudência, genericamente, em cerceamento de defesa ou de acusação." (GRINOVER, Ada Pellegrini; FERNANDES, Antonio Scarance; GOMES FILHO, Antonio Magalhães. As nulidades no processo penal. 9. ed. São Paulo: Revista dos Tribunais, 2006. p. 137-138). 
É certo, também, que ao lado da regulamentação da investigação defensiva, tornar-se-á necessário construir uma teoria da investigação defensiva, papel este atribuído à doutrina. Nessa linha, pensamos que o primeiro passo é situar o papel da investigação defensiva para o nosso sistema jurídico.

O conceito trazido por Édson Luís Baldan é pertinente, quando o autor afirma:

Investigação defensiva é o complexo de atividades de natureza investigatória desenvolvido, em qualquer fase da persecução criminal, inclusive na antejudicial, pelo defensor, com ou sem assistência de consultor técnico, tendente à coleta de elementos objetivos, subjetivos e documentais de convicção, no escopo de construção de acervo probatório lícito que, no gozo da parcialidade constitucional deferida, empregará para pleno exercício da ampla defesa do imputado em contraponto à investigação ou acusação oficial. ${ }^{46}$

Estamos de acordo com a proposição sugerida pelo autor, mas com o acréscimo de que a investigação defensiva pode também ser realizada em favor de outros sujeitos processuais, a exemplo da vítima nas suas mais variadas posições (querelante e assistente de acusação).

Importante notar também que mesmo havendo relação com o tema probatório, a atividade defensiva não necessariamente se dirigirá a uma dialeticidade com a investigação policial ou ao suporte da defesa na ação penal. Muito mais do que isso, pode ela ser exercida para fornecer subsídios em qualquer fase ou grau procedimental, inclusive para eventual embasamento de uma revisão criminal ou para aspectos na seara da execução penal (formas não prisionais de cumprimento de pena), sendo verdadeiro reflexo da paridade de $\operatorname{armas}^{47}$.

46 BALDAN, Édson Luís. Investigação defensiva: o direito de defender-se provando. Revista Brasileira de Ciências Criminais, São Paulo, v. 15, n. 64, p. 253273, jan./fev. 2007. p. 269.

47 "O esforço dirigido ao fim de configurar novos procedimentos reclama a organização de um modelo epistêmico presidido por princípios éticos que são favorecidos pela adoção do dispositivo da Discovery.

A paridade de armas sucumbe na hipótese de a acusação, por si ou através da polícia, vir a dispor de amplo conjunto de informações e este acervo terminar 
Dentre seus vários escopos ${ }^{48}$, a investigação defensiva se prestará a permitir a coleta de elementos que forneçam a construção de teses defensivas baseadas em certos fatos; favorecer a aceitação dessas teses defensivas ${ }^{49}$; permitir a formação de um percurso defensivo no processo quando o agente tenha parcela de responsabilidade pelo fato praticado; desanuviar a percepção da defesa quanto à oportunidade e conveniência na aceitação de institutos despenalizadores; antecipar a visualização de futuras colidências de defesa entre acusados; refutar a validade de provas produzidas pela acusação; ou até mesmo na própria elucidação da conduta criminosa, nesse caso, situação mais comum quando a vítima quiser participar da apuração por meio de investigação própria.

A partir desses objetivos, a defesa realiza diligências com o propósito exclusivo de identificar elementos que possam favorecer a sua situação jurídica, sem a necessária preocupação com a apuração da verdade. Poderá, entretanto, agir imbuída no espírito de clarificação da verdade, trazendo ao conhecimento da acusação informações negligenciadas pelos órgãos de Polícia Judiciária, de acordo com a impressão de Susan Haack:

A atividade de um investigador é descobrir a verdadeira resposta à sua pergunta; portanto, sua obrigação é buscar as evidências

sonegado à defesa, ainda que parcialmente, porque não foi devidamente resguardado ou até porque foi suprimido." (PRADO, Geraldo. Prova penal e sistema de controles epistêmicos. São Paulo: Marcial Pons, 2014. p. 57).

"Por ultimo, se as investigações judiciárias pecam por serem muitas vezes centradas na solução do crime, ao invés de serem dirigidas em função das necessidade de prova especificamente impostas pela lei processual penal para a condenação efectiva dos eventuais agentes do crime, pelo contrário, as investigações criminais levadas a cabo pelo próprio arguido deverão ser sempre preferencialmente dirigidas para a comprovação dos factos que depende a sua Defesa e não à solução crime, propriamente dita, pelos menos enquanto tal não for tido por necessário." (OLIVEIRA, Francisco da Costa. A defesa e a investigação do crime. 2. ed. Coimbra: Almedina, 2008. p. 57-58).

"However, defense investigators generally do not need to determine if a crime was committed. Nor do they generally need to determine who has committed the crime. Defense investigations are often focused on specific issues, the goal being to uncover evidence to support that someone did not commit the crime. Specifically, that the defendant charged with the crime is not guilty." (PERRON, Brandon A. Uncovering reasonable doubt. Nebraska: Morris Publishing, 1998. p. 1-3). 
que ele puder e avaliar o mais razoavelmente possível. Então, novamente, estritamente falando, "investigador desinteressado e imparcial é meio que um pleonasmo; um investigador interessado e tendencioso e um oximoro. Mas na vida real, obviamente, é muito mais confuso. Provavelmente ninguém é de integridade intelectual sólida, e até os mais honestos inquiridores têm seus preconceitos e pontos cegos; e um defensor ansioso para evitar ser pego de surpresa pode perguntar com escrupulosa meticulosidade. (tradução livre) ${ }^{50}$

As vantagens da investigação desenvolvida pela defesa serão inúmeras. Com um maior aproveitamento do tempo entre a data do fato e o trânsito em julgado da causa, permitir-se-á que a defesa exerça maior intervenção nos estágios iniciais, em que os elementos de formação do convencimento estão com maior frescor, proporcionando uma imediatidade entre a prática de atos investigativos e a presença da diligência.

Uma visão prévia dos elementos que pesam em desfavor do imputado permitirá uma avaliação mais acertada do seu comportamento na relação processual, com a aceleração do curso da persecução penal e a consequente aceitação de benefícios e institutos despenalizadores previstos em lei ${ }^{51}$.

50 “An inquirer's business is to discover the true answer to his question; so his obligation is to seek out what evidence he can and asses it as fairly as possible. So, again strictly speaking, 'disinterested, unbiased inquirer is kind of a pleonasm, and interested, biased inquirer an oxymoron. But in real life, obviously, it's a lot messier. Probably nobody is of rock-solid, acrossthe-board intellectual integrity, and even the most honest inquirers have their prejudices and blind spots; and an advocate anxious to avoid being blindsided may inquire with scrupulous thoroughness." (HAACK, Susan. Evidence matters: science, proof and truth in the law. New York: Cambridge University Press, 2014. p. 30).

51 "There are further complicating factors. We have already seen that a single process may involve several modes of dispute-settlement. This was not just a conceptual point. One reason for shifting the focus from adjudication to litigation was the familiar fact that a large majority of civil actions never reach trial and that in most criminal proceedings at common law, by reason of the guilty plea, the trial stage never happens, yet "evidentiary issues are involved.” (TWINNING, William. Rethinking evidence. New York: Cambridge University Press, 2006. P. 251). 
Édson Baldan enumera diversos fatores que justificam a pertinência de uma investigação defensiva em nosso sistema jurídico. Para o autor:

\begin{abstract}
Vislumbram-se como inexoráveis vários benefícios como consequência direta ou reflexa da atividade do defensor que dirige sua própria investigação, em qualquer fase ou estágio da persecução penal: a) aprimoramento da investigação policial como contraponto eficaz às provas produzidas pelo defensor, obrigando a polícia judiciária e o Ministério Público à busca de contínuo aperfeiçoamento técnico-científico; b) criação (ou hipertrofia) de uma categoria profissional: os investigadores privados; c) estímulo ao culto das ciências afins ao Direito Penal, como a Criminalística, Criminologia, Medicina Legal, com a consequente necessidade de adequação do ensino técnico e superior; d) redimensionamento da estatura jurídica do advogado (dentro e fora do processo), transmudando-o da condição de mero espectador inerme e inerte para a posição de ativo protagonista na formação da prova criminal; e) obrigação da motivação judicial na admissão da acusação, criandose verdadeiro juízo de prelibação que arredaria a instauração da instância judicial quando insuficientes os elementos indiciários e de prova; f) maior proximidade do processo penal com a verdade "real" atingível pelo fortalecimento da prova criminal, com a consequente serenidade maior do Magistrado ao proferir seu decisum com ouvidos às razões produzidas por acusação e defesa em perfeita égalité des armes. ${ }^{52}$
\end{abstract}

Se é fato que o direito à produção probatória se extrai da ampla defesa e do devido processo legal, não podemos nos esquecer de que nosso sistema busca preservar a segurança jurídica. Assim, para a validade do que denominamos de binômio validade/veracidade da informação colhida pela defesa, nada mais natural que haja uma regulamentação sobre o tema, de modo a conferir maior fiabilidade ao conteúdo do inquérito defensivo.

Relembre-se que os elementos indiciários são duramente criticados pela doutrina, especialmente as colheitas de depoimentos realizadas pelos órgãos de Polícia Judiciária. Se, mesmo nas atividades regulamentadas

52 BALDAN, Édson Luís. Investigação defensiva: o direito de defender-se provando. Revista Brasileira de Ciências Criminais, São Paulo, v. 15, n. 64, p. 253273, jan./fev. 2007. p. 269. 
pelo Código de Processo Penal, não é possível empreender veracidade absoluta ao seu conteúdo, o mesmo raciocínio deve ser aplicado à investigação defensiva e à falta de parâmetros normativos.

\section{III - A Teoria da Investigação Criminal Defensiva e a Carência Normativa a Ser Suprida}

Seria injusto afirmar a total inércia do legislador no trato da investigação defensiva. A proposta de edição de um novo Código de Processo Penal procurou contemplar o tema com a previsão de um único dispositivo, conforme se observa da redação do PLS 156/2009 (art. 13). No entanto, essa única norma não se revela suficiente para disciplinar a matéria ${ }^{53}$.

Pensamos que uma regulamentação inicial e não exaustiva da investigação defensiva pelo Código deva prever: 1 - o reconhecimento da atividade propriamente dita e os momentos em que ela pode ser realizada; 2 - as diligências e o seu modo de agir, estabelecendo limites e comportamentos, especialmente em relação aos terceiros abordados por essa investigação; 3 - o grau de publicidade da investigação defensiva e a possibilidade de utilização no inquérito policial, procedimento investigatório, ação penal ou qualquer outro momento procedimental; 4 - a possibilidade de investigação defensiva em favor de vítimas; 5 - o responsável pela condução da investigação defensiva e os sujeitos que dela farão parte; 6 - a possibilidade de amparo judicial quando houver obstáculo ao exercício da investigação defensiva.

Estes talvez sejam os aspectos de sustentação da realização da investigação direta pela defesa e, por esta razão, merecem regulamentação imediata, de forma a trazer segurança e credibilidade ao desempenho da atividade.

53 "A regulamentação em discussão no Brasil é tímida, ainda mais se comparada com a legislação italiana. Ao contrário de viabilizar a pesquisa de fontes de prova por parte da defesa, a prometida legislação parece mais querer conter uma atividade que pressupõe já em prática" (VILARES, Fernanda Regina; BEDIN, Guilherme Augusto Campos; CASTRO, Pedro Machado de Almeida. Investigação criminal: o projeto de código de processo penal e investigação defensiva. Revista Brasileira de Ciências Criminais, São Paulo, v. 22, n. 107, p. 309-336, mar./abr. 2014. p. 322). 
No campo penal e disciplinar, faz-se necessário compreender a necessidade de regulamentação pelos abusos praticado na condução da investigação, bem como pelo fornecimento de falsas informações das pessoas que intervenham na investigação defensiva.

De certo que a atividade regulamentar advinda da lei ordinária jamais será exaustiva e se conciliará também de ajustes promovidos pelo Conselho Federal da Ordem dos Advogados do Brasil por meio de seu poder regulamentar (Provimentos) e dos órgãos normativos das respectivas Defensorias Públicas (Conselho Superior), enquanto não houver um órgão nacional com essa aptidão.

Note-se que não há uma relação de antecedência entre essas atividades, o que implica admitir que os órgãos de defesa podem se antecipar ao Parlamento e editar, desde logo, normas relativas à investigação defensiva, como é o caso do recente Provimento n. 188/2018, aprovado pelo Conselho Federal da Ordem dos Advogados do Brasil.

Uma vez construído um sólido pilar normativo, o próximo passo é a teorização da investigação criminal defensiva. Esse segundo passo dependerá do estabelecimento de alguns conceitos centrais que permitam um melhor embasamento teórico e se escoram em justificativas amparadas no ordenamento jurídico.

Serão eles: a - quem desenvolve a investigação defensiva; $\mathrm{b}$ quando se desenvolve; c - como se desenvolve; $\mathrm{d}$ - o seu propósito; $\mathrm{e}-\mathrm{as}$ garantias que devem ser observadas em favor de quem é alvo da atividade investigativa defensiva; $\mathrm{f}$ - o nível de publicidade da investigação; $\mathrm{g}$ - a natureza da relação entre investigador e interessado na investigação; h a possibilidade ou não de controle, amparo e intervenção judicial; i - o regime disciplinar aplicado ao investigador; $\mathrm{j}$ - a natureza da investigação e dos atos realizados.

Outro ponto crucial a ser considerado é o que denominamos "imediação investigativa”. Décio Alonso Gomes, em sua tese sobre provas, procura justificar a relação entre prova e imediação no processo penal com foco na atividade jurisdicional ${ }^{54}$. Esse mesmo raciocínio pode ser aplicado na investigação defensiva sob o viés de que quanto maior a

54 Cf. GOMES, Décio Alonso. Prova e imediação no processo penal. Salvador: Juspodivm, 2016. 
presença da defesa na coleta de elementos, melhor será o resultado do processo na busca da verdade ${ }^{55}$.

Isso implica reconhecer que a base da teoria geral da investigação criminal defensiva está sustentada no fato de que é salutar uma maior proximidade da defesa na coleta dos elementos de prova dos fatos, seja por meio de uma maior participação no inquérito policial, seja pela iniciativa de pesquisa e coleta de fontes de prova, observados os limites que aqui serão traçados.

Com uma visão mais ampla dos elementos favoráveis e desfavoráveis à elucidação do fato criminoso, uma defesa escorada na lealdade processual pode melhor orientar o investigado/acusado a respeito do seu comportamento na relação processual.

Não se trata de propor que a defesa crie ou falseie elementos a partir da investigação por ela produzida, mas coletar elementos que passam despercebidos aos olhos da Polícia Judiciária e da acusação e que possam, de algum modo, influir na compreensão adequada do fato posto em julgamento.

É notório que a atividade investigativa pode se desenvolver por várias linhas e, à medida que o trabalho de inteligência e coleta de elementos segue adiante, a autoridade policial ou o Ministério Público acabam por eliminar hipóteses e focar seu olhar em um único percurso formativo da opinio delicti.

Não se negue que a atividade de investigação defensiva também pode focar em um único rumo e ainda ser desenvolvida por alguém que representa uma parte da relação processual, naturalmente uma atividade interessada e, por conta disso, parcial. No entanto, a parcialidade da defesa na condução da investigação se restringe ao campo da expectativa, ou seja, se direciona na busca de certo resultado da causa e não em relação ao conteúdo da prova, imutável, como regra geral.

55 “A imediação refere essencialmente à eficácia da prova no processo, e, assim, à efetividade dos procedimentos judiciais, pois supõe a exclusão de toda intermediação artificial entre o juiz e a prova. O instituto consiste em perceber os meios de prova utilizados em juízo na presença ininterrupta de todos aqueles que desenvolvem alguma função autorizada pela lei (sujeitos processuais) e como condição de validade de sua análise para que o tribunal determine os elementos do caso singular que suportarão a decisão." (GOMES, Décio Alonso. Prova e imediação no processo penal. Salvador: Juspodivm, 2016. p. 43). 
O papel da defesa, então, é o de explorar essas linhas abandonadas pelos órgãos de investigação e, eventualmente, apontar informações que possam melhor contribuir para o esclarecimento da verdade, especialmente como forma de contrapor elementos que serão produzidos no curso da ação penal ${ }^{56}$.

Tradicionalmente, a investigação desenvolvida pela polícia judiciária utiliza-se de um verdadeiro filtro, buscando canalizar os dados que terão serventia ao esclarecimento do fato e desprezando elementos que não apresentam pertinência ao fim a que o procedimento se destina. Esse abandono de linhas investigativas pode ser explorado pela defesa, especialmente se do aspecto desprezado seja possível extrair informações de utilidade da defesa.

A atividade investigativa se desenvolverá no âmbito de um procedimento denominado inquérito defensivo, conduzido por advogado regularmente inscrito na Ordem dos Advogados do Brasil mediante regulamentação do Conselho Federal da OAB, com base no art. 54, V, da Lei 8.906/1994, ou pela Defensoria Pública, por meio de órgão de atuação com atribuição definida pelo seu Conselho Superior, amparado no art. 102, § $1^{\circ}$, da Lei Complementar 80/1994.

Ambas as normas regulam o poder normativo das instituições de defesa e permitem que haja um regramento mais detalhado do exercício da advocacia e da assistência jurídica em favor do imputado.

De certo modo, haverá uma distinção correspondente à natureza do inquérito defensivo a depender de quem o presida. Sendo o procedimento instaurado no âmbito da Defensoria Pública, correto será enquadrar a sua natureza como de ato oficial e público. O caráter oficial é comum a ambos os sujeitos que o instaurem, já que essa característica advém do fato de o inquérito defensivo ser desenvolvido por duas instituições essenciais à função jurisdicional do Estado, com sede constitucional.

É induvidoso também que a atividade desempenhada pela Defensoria Pública na condução de um inquérito defensivo ostenta natureza

56 "A transparência que abarca a realização das atuações processuais na presença das partes e de terceiros, constitui um freio no exercício de um poder do qual é tão fácil abusar." (GOMES, Décio Alonso. Prova e imediação no processo penal. Salvador: Juspodivm, 2016. p. 43). 
de ato investigatório público, por se tratar de instituição organizada pelo Estado e dedicada à assistência jurídica dos necessitados.

No entanto, há uma qualificação diversa da natureza do procedimento, quando tratamos da advocacia. Poder-se-ia cogitar da possibilidade de se atribuir a natureza pública aos atos investigativos produzidos por advogado, considerando que o art. $2^{\circ}, \S 1^{\circ}$, do Estatuto da OAB afirma que no ministério privado o advogado presta serviço público e exerce função social, o que reforçaria essa natureza pública da atividade de investigação defensiva ${ }^{57}$.

No entanto, ainda que possível a construção teórica em prol da função do advogado, sua relação com o cliente reveste-se de particularidades não reproduzidas no regime estabelecido entre Defensoria Pública e os seus assistidos, o que seria um primeiro fator a caracterizar a natureza jurídica diversa entre os inquéritos defensivos.

Assim, na base da teoria, teremos uma distinção formal entre a investigação desenvolvida pela Defensoria Pública, que, pela sua natureza estatal e oficial, terá natureza pública, e a investigação desenvolvida pelo advogado, que, pela sua natureza, ostentará natureza privada.

É bem verdade que a natureza pública do inquérito defensivo e dos atos que nele são praticados servirá de pouca utilidade para a sua aplicação prática, considerando que o conteúdo da investigação é que será submetido à valoração durante a fase de investigação criminal e do processo penal, pouco importando se de natureza pública ou privada.

Não se evidencia adequado querer atribuir maior valor para formação do convencimento, conforme a natureza da investigação (pública ou privada). O que importa é se os atos praticados se destinam à utilização para a opinio delicti da acusação ou no curso de um processo penal, e se foram praticados observando-se as regras procedimentais de modo a preservar a licitude e a veracidade de seu conteúdo.

57 "Prosseguindo na discussão, é preciso dizer que a atividade advocatícia, como uma profissão que exerce um múnus público (art. 133, CF), poderia possuir fé pública no sentido de conferir autenticidade aos documentos por si atestados.” (DIAS, Gabriel Bulhões Nóbrega. A advocacia criminal, a investigação defensiva e a luta pela paridade de armas. Revista Brasileira de Ciências Criminais, São Paulo, v. 26, n. 150, p. 145-187, dez. 2018. p. 153). 
Como forma de atribuir ainda mais fidedignidade à atividade desempenhada pelos advogados, não nos parece irrazoável que a Ordem dos Advogados do Brasil mantenha o controle de um banco de dados dos advogados que pretendam realizar a investigação defensiva e deles exija frequência em cursos periódicos de capacitação, especialmente para a construção de um perfil ético na condução dessa nova função.

Um primeiro passo foi dado com a regulamentação da investigação defensiva, a partir do Provimento n. 188/2018 do Conselho Federal da OAB. Todavia, a autarquia profissional pouco se preocupou na relação com o controle dos atos investigativos realizados pelos advogados

Um tema de tal envergadura, especialmente diante da ausência de um amparo legislativo regulamentar, não depende de um ato administrativo que apenas discipline a forma de instauração do inquérito defensivo, mas também enfrente os aspectos deontológicos na sua condução.

Há um perigo de se tomar um rumo semelhante ao dos acordos de não persecução aprovados no âmbito do CNMP, cuja constitucionalidade é discutida no STF em virtude de um excessivo avanço normativo em temas que não competiriam ao Conselho, até o advento da Lei n. 13.964/2019 que trouxe maior disciplina ao tema.

Em sequência ao nosso raciocínio, o gênero investigação criminal defensiva tem por objeto a defesa de interesses de sujeitos que não fazem parte da atividade de Polícia Judiciária e Ministério Público, mas que, por força das regras do ordenamento jurídico, podem ocupar posições na relação processual (indiciado, acusado, querelante, vítima e assistente de acusação) e desejam realizar atos paralelos a outras formas de investigação criminal.

A investigação criminal defensiva, ou também, para a defesa de interesses pode ocorrer por meio de um inquérito defensivo, instrumento destinado à coleta de informações em favor de suspeitos, indiciados, acusados e condenados ou por meio de um inquérito auxiliar, quando realizado pelo querelante, vítima ou assistente de acusação.

Isso quer dizer que a investigação criminal defensiva se desdobra: 1 - no inquérito defensivo quando o seu interessado ocupa posição de sujeito ativo de determinada conduta criminosa; 2 - no inquérito auxiliar quando o interessado ocupa a posição de sujeito passivo de determinada infração penal. 
Em sentido mais ampliativo, Gabriel Bulhões propõe uma classificação quadripartida da investigação defensiva, podendo ela ter os escopos de fornecer suporte ao imputado, à vítima, em contexto empresariais (incluídos aspectos não criminais) e com contexto em colaboração premiada ${ }^{58}$.

Por fim, com a definição da essência da atividade defensiva de coleta de informações, restará apenas estabelecer quais atos o defensor pode praticar quando do desempenho da investigação defensiva com amparo nas normas jurídicas atualmente em vigor, sem prejuízo de eventuais sugestões normativas que serão apresentadas.

De plano, torna-se importante definir uma enumeração não exaustiva, o que implica reconhecer que a complexidade de determinados fatos pode trazer à luz o potencial de outras diligências de interesse da defesa, até mesmo por conta da evolução da sociedade e da ciência, capazes de proporcionar novas formas de reprodução dos fatos.

Como o legislador nem sempre é capaz de estar à frente de seu tempo, certamente a defesa técnica se verá diante de situações em que a busca por fontes de prova decorra de atividades até então inéditas.

Assim, os meios atípicos de coleta de informações no curso da investigação defensiva poderão ser empregados desde que moralmente legítimos e mesmo que não expressos nas normas do Código de Processo Penal, reforçando-se a missiva de que o rol ora proposto tem caráter meramente enunciativo, nas palavras de Giuseppe Locatelli e Giulio Sarno:

A proibição de o advogado executar medidas de investigação tipificadas pelo código, diferentes daquelas cujo cumprimento é autorizado pelas regras relativas às investigações defensivas não exclui, em princípio, a legitimidade do advogado para levar a cabo investigações atípicas de acordo com o princípio da

58 "Surge, assim, para o advogado, na área criminal, algumas possibilidades de atuação. Para fins didáticos, portanto, propõe-se a seguinte taxonomia, sendo encarada a investigação defensiva (lato sensu) como um gênero, do qual fazem parte quatro espécies: i) investigação defensiva stricto sensu; ii) investigação defensiva dos interesses das vítimas; iii) investigação defensiva corporativa; e, ainda, iv) investigação defensiva colaboracional.” (DIAS, Gabriel Bulhões Nóbrega. A advocacia criminal, a investigação defensiva e a luta pela paridade de armas. Revista Brasileira de Ciências Criminais, São Paulo, v. 26, n. 150, p. 145-187, dez. 2018. p. 154). 
admissibilidade de prova não regulada pela lei previsto pelo art. 189 do CPP. (tradução livre) ${ }^{59}$

Fora esse contexto, torna-se possível admitir que a defesa possa: 1 - coletar e registrar depoimentos; 2 - requisitar documentos e informações; 3 - realizar exames e contraprovas periciais; 4 - examinar o local e os instrumentos do crime com apoio de assistente técnico; 5 - contar com o depoimento de especialistas; 6 - ter acesso a bancos de dados de natureza pública; 7 - ter acesso às informações de seu constituinte; 8 valer se de dados da vítima e de terceiros disponíveis em meios públicos de acesso à informação.

Com regras transparentes sobre a investigação defensiva e um norte adequado ao seu exercício, a persecução penal será melhor exercida no contexto da paridade de armas, dispondo a defesa de mecanismos suficientes para debater as provas durante a relação processual.

\section{Conclusão}

Diante do pensamento exposto nesse estudo, podemos aqui traçar algumas conclusões sobre a atividade apuratória conduzida pela defesa técnica sob a estrutura da investigação defensiva.

O interesse da defesa em provar determinados fatos pode se inserir em contexto de estratégia probatória, com vistas à extinção prematura de uma ação penal, seja pelo juízo de rejeição da denúncia ou da absolvição sumária.

Podemos considerar que embora a defesa não tenha um ônus de prova equivalente ao do Ministério Público a ela se atribui o ônus de

59 "No primeiro caso, seriam então atípicos os eventuais instrumentos não previstos em lei, embora não seja fácil identificar meios diversos daqueles já referidos pelo legislador, dado que as fontes de prova são limitadas, assim como o são as possíveis modalidades da função representativa. Isso vale até para os meios resultantes do desenvolvimento tecnológico porque se reduzem sempre às noções de documento ou perícia, submetendo-se às regras que disciplinam tais modalidades probatórias." (GOMES FILHO, Antonio Magalhães. Notas sobre a terminologia da prova: reflexos no processo penal brasileiro. In: YARSHELL, Flávio Luiz; MORAES, Maurício Zanoide de (Org.). Estudos em homenagem à professora Ada Pellegrini Grinover. São Paulo: DSJ Ed., 2005. p. 303-318. p. 314). 
comprovar fatos ou elementos que gerem dúvida suficiente para a absolvição e daí a necessidade de seu fortalecimento através da possibilidade de realização da investigação defensiva.

Certo das particularidades dos sistemas norte-americano e italiano, a experiência de investigação criminal defensiva de ambos os países contribui para a compreensão do tema no Brasil, especialmente o desenho do instituto;

Isso nos leva a perceber que a atividade de investigação criminal não pode mais ser encarada como sinônimo de inquérito policial e polícia judiciária. Outras formas de investigação são admitidas pelo ordenamento jurídico, a exemplo da investigação direta pelo Ministério Público e as investigações produzidas em procedimentos sancionatórios;

Com a ampliação do conceito de investigação criminal, torna-se possível inserir a investigação defensiva como uma de suas espécies, compreendida através do inquérito defensivo (em favor do imputado) e do inquérito auxiliar (em favor da vítima);

Algumas normas de nosso sistema jurídico já se revelam adequadas como instrumental para o desenvolvimento de investigações pela defesa. Todavia, para uma efetiva investigação defensiva, outros ajustes tornar-se-ão necessários, principalmente ao Código de Processo Penal e nas leis que regem a advocacia e Defensoria Pública.

A investigação defensiva permitirá que o imputado possa contribuir no esclarecimento dos fatos, avaliar como deve ser o seu comportamento na relação processual, valorar a pertinência de aceitação de acordos processuais e institutos despenalizadores.

A atividade prévia da defesa na identificação de fontes de prova certamente lhe conferirá os instrumentos necessários para resistir à pretensão acusatória, apontado a fragilidade da prova produzida pelo Ministério Público, produzindo provas a respeito de determinados fatos ou até mesmo persuadindo o juiz a encarar a dúvida do material probatório.

\section{REFERÊNCIAS}

AMERICAN BAR ASSOCIATION. Section of criminal justice. Criminal justice standards for the defense function: fourth edition, Illinois, June, 2016. Disponível 
em: <https://www.americanbar.org/groups/criminal_justice/standards/DefenseFunctionFourthEdition-TableofContents/>. Acesso em: 27 nov. 2019.

ARAÚJO, José Aurélio de. Cognição sumária, cognição exaustiva e coisa julgada. São Paulo: Revista dos Tribunais, 2017.

BADARÓ, Gustavo. Processo Penal. 4. ed. São Paulo: Revista dos Tribunais, 2016. BALDAN, Édson Luís. Investigação defensiva: o direito de defender-se provando. Revista Brasileira de Ciências Criminais, São Paulo, v. 15, n. 64, p. 253-273, jan./ fev. 2007.

BENTHAM, Jérémie. De l'organisation judiciare, et de la codification. Paris: Librairie de Hector Bossange, 1828.

CAVACO, Bruno de Sá Barcelos. Desjudicialização e resolução de conflitos. Curitiba: Juruá, 2017.

CONSO, Giovanni; ILLUMINATI, Giulio. Commentario breve al codice di procedura penale. Milano: CEDAM, 2014.

CURTOTTI, Donatella. L'esercizio del diritto di difesa nelle indagini preliminari. In: NEGRI, Daniele. Le indagini preliminari e l'udienza preliminare. Torino: G. Giappichelli Editore, 2017. (Trattato teorico pratico di diritto processuale penale, v. 5).

DAMAŠKA, Mirjan R. Evidence law adrift. London: Yale University Presse, 1997.

DI CHIARA, Giuseppe. Le linee prospettiche del difendersi ricercando: luci e ombre delle nuove investigazioni difensive. La legislazione penale, Jovene, v. 22, n. 1-2, p. 1-28, gen./mar. 2002.

DIAS, Gabriel Bulhões Nóbrega. A advocacia criminal, a investigação defensiva e a luta pela paridade de armas. Revista Brasileira de Ciências Criminais, São Paulo, v. 26, n. 150, p. 145-187, dez. 2018.

FAZZALARI, Elio. Instituzioni di diritto processuale. 6. ed. Milano: CEDAM. 1992. GOMES, Décio Alonso. Prova e imediação no processo penal. Salvador: Juspodivm, 2016.

GOMES FILHO, Antonio Magalhães. Notas sobre a terminologia da prova: reflexos no processo penal brasileiro. In: YARSHELL, Flávio Luiz; MORAES, Maurício Zanoide de (Org.). Estudos em homenagem à professora Ada Pellegrini Grinover. São Paulo: DSJ Ed., 2005. p. 303-318.

GRECO, Leonardo. Garantias fundamentais do processo: o processo justo. In: GRECO, Leonardo. Estudos de Direito Processual. Campos dos Goytacazes: Editora Faculdade de Direito de Campos, 2005.

GRIMM, Paul W; FAX, Charles S.; SANDLER, Paul Mark. Discovery problems and their solutions. Chicago: American Bar Association, 2014. 
GRINOVER, Ada Pellegrini; FERNANDES, Antonio Scarance; GOMES FILHO, Antonio Magalhães. As nulidades no processo penal. 9. ed. São Paulo: Revista dos Tribunais, 2006.

HAACK, Susan. Evidence matters: science, proof and truth in the law. New York: Cambridge University Press, 2014.

HENDLER, Edmundo S. Derecho penal y procesal penal de los estados unidos. Buenos Aires: Ad-Hoc, 2006.

MACHADO, André Augusto Mendes. Investigação criminal defensiva. São Paulo: Revista dos Tribunais, 2010.

MADDALENA, Marcello. Per la difesa libera di investigare facoltà e diritti, nessun dovere. Diritto e giustizia, Milano, n. 40, nov. 2000.

MALAN, Diogo Rudge. Investigação defensiva no processo penal. Revista Brasileira de Ciências Criminais, São Paulo, v. 20, n. 96, maio/jun. 2012.

MALAN, Diogo Rudge. Defesa penal efetiva. Ciências Penais: Revista da Associação Brasileira de Professores de Ciências Penais, São Paulo, v. 3, n. 4, p. 253-277, jan./jun. 2006.

MARQUES, José Frederico. Elementos de direito processual penal. Campinas: Bookseller, 1998. 4 v. V. 2.

MAZZA, Oliviero. Fascicolo del difensore e utilizzabilità delle indagini defensive. In: REPERTORIO generale annuale della giurisprudenza italiana. Torino: UTET, 2002. 2 v.

MCCONKIE, Daniel S. Structuring pre-plea criminal discovery. The Journal of Criminal Law \& Criminology, Evanston, v. 107, n. 1, p. 1-34, May 2017.

NARDELLI, Marcella Alves Mascarenhas. O direito à prova e à não autoincriminação em uma perspectiva comparada entre os processos civil e penal. Revista de Processo, São Paulo, v. 40, n. 246, p. 171-198, ago. 2015.

OLIVEIRA, Francisco da Costa. A defesa e a investigação do crime. 2. ed. Coimbra: Almedina, 2008.

PAPERNO, Jill. Representing the accused. Minnesota: Aspatore, 2012.

PERRON, Brandon A. Uncovering reasonable doubt. Nebraska: Morris Publishing, 1998.

PRADO, Geraldo. Prova penal e sistema de controles epistêmicos. São Paulo: Marcial Pons, 2014.

PRIOTTI, Giuliana. Le investigazioni difensive: la conclusione di una storia infinita. Questione Giustizia, Roma, n. 1, gen./feb. 2001. 
PUIGVERT, Silvia Pereira. La exhibición de documentos y soportes informáticos en el proceso civil. Navarra: Arazandi, 2013.

RAMOS, Vitor de Paula. Direito fundamental à prova. Revista de Processo, São Paulo, v. 38, n. 224, p. 41-61, out. 2013.

SAAD, Marta. O direito de defesa no inquérito policial. São Paulo: Revista dos Tirbunais, 2004. (Coleção Estudos de Processo Penal Prof. Joaquim Canuto Mendes de Almeida, v. 9).

SIRACUSANO, Delfino et al. Diritto processuale penale. Milano: Giuffrè, 2009.

TARUFFO, Michele. La prueba. Madrid: Marcial Pons, 2008.

TWINNING, William. Rethinking evidence. New York: Cambridge University Press, 2006.

VELANI, Luigi Gino. Le investigazioni preventive. Milano: Giuffrè, 2012.

VILARES, Fernanda Regina; BEDIN, Guilherme Augusto Campos; CASTRO, Pedro Machado de Almeida. Investigação criminal: o projeto de código de processo penal e investigação defensiva. Revista Brasileira de Ciências Criminais, São Paulo, v. 22, n. 107, p. 309-336, mar./abr. 2014.

\section{Informações adicionais e declarações dos autores (integridade científica)}

Declaração de conflito de interesses (conflict of interest declaration): o autor confirma que não há conflitos de interesse na realização das pesquisas expostas e na redação deste artigo.

Declaração de autoria e especificação das contribuições (declaration of authorship): todas e somente as pessoas que atendem os requisitos de autoria deste artigo estão listadas como autores; todos os coautores se responsabilizam integralmente por este trabalho em sua totalidade.

Declaração de ineditismo e originalidade (declaration of originality): o autor assegura que o texto aqui publicado não foi divulgado anteriormente em outro meio e que futura republicação somente 
se realizará com a indicação expressa da referência desta publicação original; também atesta que não há plágio de terceiros ou autoplágio. Destaca-se que o presente estudo revisita algumas das premissas lançadas na obra Investigação Criminal Direta pela Defesa (Salvador: JusPodium, 2019) com um olhar mais focado na atividade probatória das partes, com o acréscimo de novas considerações sobre o tema.

Dados do processo editorial (http://www.ibraspp.com.br/revista/index.php/RBDPP/about/editorialPolicies)

- Recebido em: 14/12/2019

- Controle preliminar e verificação de plágio: 15/12/2019

- Avaliação 1: 30/12/2019

- Avaliação 2: 31/12/2019

- Avaliação 3: 07/01/2020

- Decisão editorial preliminar: 08/01/2020

- Retorno rodada de correções: 05/02/2020

- Decisão editorial final: $16 / 02 / 2020$

\section{Equipe editorial envolvida}

- Editor-chefe: 1 (VGV)

- Editor-assistente: 1 (MSG)

- Revisores: 3

\section{COMO CITAR ESTE ARTIGO:}

SILVA, Franklyn R. A. A investigação criminal direta pela defesa - instrumento de qualificação do debate probatório na relação processual penal. Revista Brasileira de Direito Processual Penal, Porto Alegre, vol. 6, n. 1, p. 41-80, jan./abr. 2020. https://doi.org/10.22197/rbdpp.v6i1.308

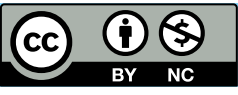

Esta obra está licenciada com uma Licença Creative Commons Atribuição-NãoComercial 4.0 Internacional. 